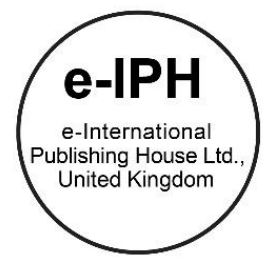

\title{
The Physical Factors Affecting to Student's Life in Higher-Education: A Case Study on Wheelchair-Bounded Students in a Private University
}

\author{
Sridara Tipian ${ }^{1 *}$, Antika Sawadsri ${ }^{2}$ \\ ${ }^{1 *}$ Arch D. Student, Multidisciplinary Design Research Program, ${ }^{2}$ Asst. Prof., Ph.D. \\ Faculty of Architecture, King Mongkut's Institute of Technology Ladkrabang (KMITL) 10520, Thailand \\ t_darada@hotmail.com \\ Tel: +66 618468885
}

\begin{abstract}
There are $48.37 \%$ in Thailand, who use wheelchairs, but they can be learned. The percentage of the disabled who are in higher education system only $1.61 \%$. The result of physical factors where are not ready. This research focused study of physical factors affecting to wheelchair-bounded student by qualitative research; survey, access audit and the semi-structured interview. Found that factors affecting are entrance, classroom, activities area and restroom. Enhancing technical knowledge to the building manager to responding to all usage. Contributors often avoid seeking help because don't want to feel like a burdensome. The most important is that family are another motive to study.
\end{abstract}

Keywords: Physical Factors, Wheelchair-Bounded Students, Management education for disabled;

eISSN: 2398-4287C 2017. The Authors. Published for AMER ABRA by e-International Publishing House, Ltd., UK. This is an open access article under the CC BYNCND license (http://creativecommons.org/licenses/by-nc-nd/4.0/). Peer-review under responsibility of AMER (Association of Malaysian Environment-Behaviour Researchers), ABRA (Association of Behavioural Researchers on Asians) and cE-Bs (Centre for Environment-Behaviour Studies), Faculty of Architecture, Planning \& Surveying, Universiti Teknologi MARA, Malaysia.

https://doi.org/10.21834/e-bpj.v2i6.975

\subsection{Introduction}

The disabled person is not just the congenital deformation, there are also a number of the disabled person from illness or accident. Disability affects both mentally and socially. If, it happens to people in school-age will affect the development of skills, learning and intellect. The loss of facilities to access their educational services also hinders the development of vocational skills for the disabled. (Komolkiti, 2008) From The reported on disabled person in Thailand, September 2016, It was shown that 1,657,438 peoples had been issued ID cards. Currently, they were in the all education levels system 998,846 peoples or $60.26 \%$. They only received 16,051 $(1.61 \%)$ of their undergraduate and master's degrees despite the fact that there were 794,648 peoples $(48.37 \%)$ of disabled person, who does not have a learning disability. Why disabled peoples are not attending higher-education?...If disabled peoples graduate bachelor degrees, they will have the opportunity to work for higher positions and higher incomes. They also can care for themselves and their family. It appears that the education is the basic that the disabled person should receive. There may be several causes are important factor that disabled students lose opportunity and access to educational services. For instance, physical, mental, or intellectual defects and the lack of education facilities and the disabled person help-systems that affect potential learning (Tieammanee, 2009). This article reflects on qualitative research processes and research that focus on the study and understanding of the lives of disabled students. There are two main objectives. Firstly, to study and investigate spatial physical factors affecting the disabled students using wheelchairs. Second, to study attitudes of disabled students using wheelchairs in a university life and propose the physical and social factors affecting the lives of disabled students using wheelchairs. It is expected that this research will support

eISSN: 2398-4287@ 2017. The Authors. Published for AMER ABRA by e-International Publishing House, Ltd., UK. This is an open access article under the CC BYNCND license (http://creativecommons.org/licenses/by-nc-nd/4.0/). Peer-review under responsibility of AMER (Association of Malaysian Environment-Behaviour Researchers), ABRA (Association of Behavioural Researchers on Asians) and cE-Bs (Centre for Environment-Behaviour Studies), Faculty of Architecture, Planning \& 
policies as being a driving force in creating the right environment for disabled students at university and also be motivation to disabled students want to learn in higher education. The research process was qualitative data collection; survey, access audit and semistructured interview by three disabled students using wheelchairs. The questionnaire can identify activities and behaviours that cause problems and obstacles to the use of space and gives an insight into attitudes of university life of disabled students using wheelchairs.

The paper consists of five sections. The immediate following discusses on the theoretical perspectives behind understandings accessible physical from two paradigms (2.1 and 2.2). The third part is a method of conducting research and collecting qualitative data in 2 steps. The fourth provides research findings and discussions of physical factors affecting to wheelchair-bounded student's life in a university. The final section concludes suggestions on how to use and shows how this choice affects the attitude of students with disabilities. Including qualitative research methods in the study of the disabled and accessible environment.

\subsection{Literature Review}

\subsection{Accessibility as an educational services for disabled students}

1) The concept of universal design for disabled students

In Thailand, the first phase of operation in public buildings, Such as hospitals, health centre and utilities. Developed and implemented in residential areas, such as dormitory, residential and hotel. (Sawangjaroen, Sirisali, \& Sahavacharin, 2012) Currently, the University is a place that has a role in society and to develop human capital for national development. Because, they are going to step into adulthood, should have good interaction and understanding with other people, can to work in groups, living happily in society and especially when the graduate student goes into careers. This is an important role for all people, no matter what the difference. This research has adopted the principles and theories of design for everyone, to develop the physical accessibility for facilities the independent living of disabled students and participation in society. University should have facilities that allow equal access to education and friendly to all members.

2) Essential physical factors within the university that affect to wheelchair-bounded students

Studying the physical factors that apply the concept of universal design is critical to bringing to a campus environment that accommodates students with disabilities and friendly to all members. Design guidelines refer to the elements that are necessary to facilities access and gives everyone an opportunity to participate in various educational activities. From the results, it was found that physical factors and facilities of educational institutes were based on the principles and theories of design for everyone and the requirements of Thai law. Which were 1) Basic convenience facilities for disabilities as per the council of ministers dated May 19 , 2009. 2) The facilities in buildings as per ministerial cabinet B.E. 2005 3) Literature review for facilities of universal design on campus (Atkinson, Dorris, Miller, Ortiz \& Royal, 2013) Physical Factors affecting access to area of wheelchair-bounded student divided into two parts:

Table 1. Physical factors affect to wheelchair-bounded student

\begin{tabular}{l|l}
\hline \multicolumn{1}{c|}{ physical factors - Outdoor } & \multicolumn{1}{c}{ physical factors - Indoor } \\
\hline 1.Seating & 1.Ramps into the building \\
2.Path way/ walk way & 2.Entrance \\
3.Parking & 3.Elevator \\
4.Curbs Ramps & 4.Restroom \\
5.Outdoor-Ramps & 5. Door \\
6. pedestrian crossing & 6. Information \\
7. Street Furniture & 7. Corridor \\
& 8. Classroom \\
& \\
& \\
\hline
\end{tabular}

From the physical factors necessary to reach the area, and participation in various activities in the university. Following to Table 1. In this research will be guided method, research tools and an approach to analysis and recommended the physical factors that affect to wheelchair-bounded student's life in the university. 


\subsection{Improving the quality of life of the disabled and management education for disabled}

Thailand has the concept of developing the disabled by providing the necessary welfare. It also plans to improve the quality of life of people with disabilities at international level. Human rights concept, as a member of an international organisation, Thailand must implement the disability Plan. The equal opportunity to people with disabilities, rehabilitation of the disabled, highlight the opportunity for people with disabilities to participate fully in society, education for the disabled, employment of the disabled, access to built environment and public transport, access to information and communication, as well as information technology, including technology facilities and alleviating poverty. (Tieammanee, 2009)

The situation at the national level during the past Thailand has prepared a plan to improve the quality of national life. It is a master plan that defines Thailand's approach to disability for all public, private, and related sectors. National Plan for Quality of Life No.4 (2012-2016). The details and goals are that society has an environment where everyone can access and utilise it equally, people with disabilities have access to effective management systems (such as health, education, careers), promoting constructive attitude, disabled people have the confidence to realize the value and their dignity. Including the participation of disabled people with economic, politics, society and culture. In addition, the government has also supported and given the right to get help from the disability rehabilitation act and the national education act, the promotion of education for individuals with disabilities is required or people who cannot support themselves must give the right and opportunity to receive basic education.

Review concepts to improve the quality of life of people with disabilities both globally and nationally found that most of the goals require people with disabilities to have access to educational services. The government of Thailand has developed legislation to focus on dealing with education for students who are different and the act promotes the physical aspect.

\subsection{Methodology}

This research focused on the study of the physical environment in a private university in Bangkok. The interviewees were three wheelchair-bounded students, consists of 2 steps. Based on a qualitative approach. From the conceptual framework (See Fig.1) demonstrates access to education services for disabled students, quality of life and Management education for disabled people. Both of these ideas will lead to a search for physical factors affect to wheelchair-bounded student's life in a university divided into two parts as followed:

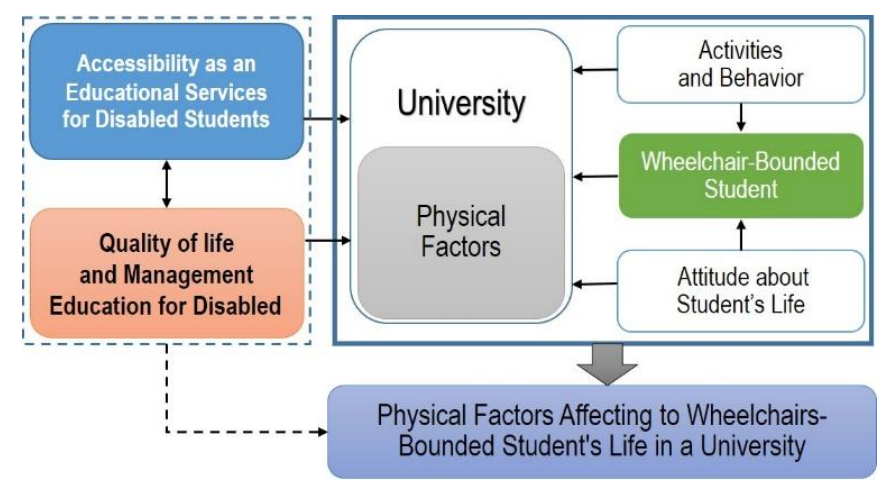

Fig. 1: Conceptual Framework

3.1 survey of physical factors and access audit by wheelchair-bounded student

1) Survey of physical factors, both indoors and outdoors, including facilities within a private university in Bangkok, by checklist based on a survey that follows the principles and theories of universal design and followed the design guide for everyone. This research was conducted with only one the university because it is qualitative research and can be to collect insights. Take a survey of the elements that are essential to the access of students who use wheelchairs, take notes, observation and photography. Divided into two factors into the physical characteristics and the facilities needed. (Atkinson, Dorris, Miller, Ortiz \& Royal, 2013) 1) Physical factors - outdoor were; seating, pathway/walkway, parking, curbs ramps, outdoor-ramps, street landscape, pedestrian crossing, street furniture 2) Physical factors - indoor were; ramps into the building, entrance, elevator, restroom, tactile surface, door, information, corridor and classroom. (Tipian \& Sawadsri, 2017)

2) Access audit by wheelchair-bounded student by evaluating the use of physical factor and facilities that affect the living of students who use wheelchair, together with user satisfaction regarding quality. One wheelchair-bounded student is easy to test by repeated experiment 3 times. This data was analyzed for qualitative results.

3.2 Semi-structured in-depth interview by three wheelchair-bounded students

From the "social model of disability" (Oliver, 1990), the disabled are excluded from society by their environment and attitudes. The results of the research show that the awareness of the ability of the disabled is empowering the disabled. (Sawadsri, 2012) The perspective of the set of ideas and findings found that semi-structured interviewing methods will reveal the critical components of the 
attitude of wheelchair-bounded student's life in a university and lead to other findings by conducting individual interviews.1) Mr.Komsan: 27 years old 2) Ms.Jinjutha: 22 years old 3) Ms.Nattaporn: 24 years old, take in an interview with one person 45-60 Minutes., use a voice recorder, taking note and photography.

\subsection{Findings and Discussions}

From the research process, the physical factors that affect to wheelchair-bounded student's life can be divided into two parts: First part is the results of a physical survey and access audit by wheelchair-bounded student. Part 2 is the result of research and findings from semi-structured in-depth interviews on attitudes of wheelchair-bounded student's life in the university.

4.1 Physical factors affecting to wheelchair-bounded student

Physical factors survey by private university case study in Bangkok metropolitan area, which developed the universal design in the beginning and to know the obvious obstacles. The results were described in the table below. The physical factors outdoor and indoor affecting shown that in Table 2. and Table 3. The results of barriers and usage problems shown that in Table 4.
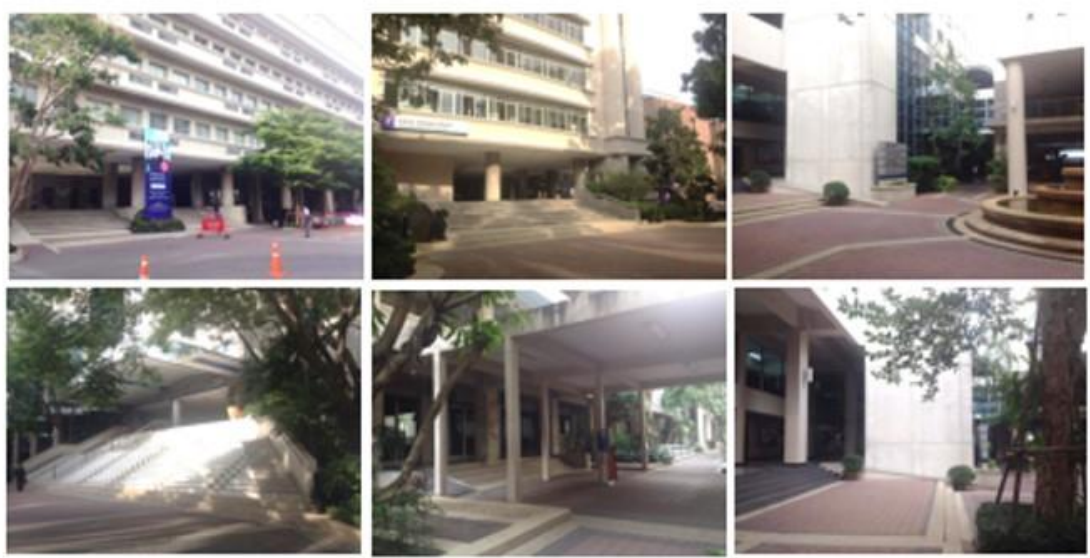

Fig.2: Physical Environment of Case Study

Table 2. Shown results of physical factors-outdoor

\begin{tabular}{|c|c|c|}
\hline Physical factors-outdoor & Survey results & Physical feature \\
\hline 1.Seating & $\begin{array}{l}\text { Along the pathway found outdoor every distance for some parts. } \\
\text { Seats were up stepped from ground more than } 10 \mathrm{~cm} \text {. }\end{array}$ & \\
\hline 2.Pathway/walkway & $\begin{array}{l}\text { Pathways have been wide enough but lowered level and slope to } \\
\text { the road only one side }\end{array}$ & \\
\hline 3.Parking & $\begin{array}{l}\text { Disabled parking has been reserved in the centre area near study } \\
\text { buildings and office of the president, accessible standard size } 2.4 \mathrm{x} \\
6.00 \mathrm{~m} \text {. free space for movement but no signs and symbols to } \\
\text { show. }\end{array}$ & \\
\hline 4.Curbs Ramps & $\begin{array}{l}\text { The curbs ramps had been standard with different colours to show } \\
\text { the steps of roadsides but without tactile surface to be advised. }\end{array}$ & \\
\hline 5.Ramps & The steps outside been not much, so no ramps were made. & \\
\hline
\end{tabular}




\begin{tabular}{l|l|l|}
\hline 6.pedestrian crossing & $\begin{array}{l}\text { The steps between the road and footpath are equally, anyway no } \\
\text { alarm-signs }\end{array}$ & $\begin{array}{l}\text { Outdoor signs and symbols found only some and were standing } \\
\text { under 2.00m. Electric poles were high, no alarm-warning }\end{array}$ \\
\hline 7.Street Furniture & &
\end{tabular}

From Table 2 university had paid intention to the accessibility and taken action as per the legal requirements as well. The other necessities were not in process as per the universal design such as; aisle seats were not convenient to the disabled to step up over $10 \mathrm{~cm}$., parking area reserved for disabled only $1-2$ places with no signs to be shown.

Table 3. Shown results of physical factors-indoor

\begin{tabular}{|c|c|c|}
\hline Physical factors-outdoor & Survey results & Physical feature \\
\hline 1.Ramps & $\begin{array}{l}\text { Most of the university's buildings built consecutively and before the } \\
\text { legal requirements. Some ramps could use for the disabilities but some } \\
\text { could not just for delivering. }\end{array}$ & \\
\hline 2.Entrance & $\begin{array}{l}\text { The ground floor had enough free space for activities; an elevator was } \\
\text { reachable. Doors are wide } 1.00 \mathrm{~m} \text {. With automatic hinge device. }\end{array}$ & \\
\hline 3.Elevator & $\begin{array}{l}\text { Study buildings have two elevators with both small and big sizes, have } \\
\text { movable space around } 1.50 \mathrm{~m} \text {., radius in front of the elevators, push } \\
\text { buttons are at the suitable positions, no colours, no alarm surface, no } \\
\text { mirror and handrails inside. }\end{array}$ & \\
\hline 4.Restroom & $\begin{array}{l}\text { Been not arranged for the disabled in the buildings built before the legal } \\
\text { requirements }\end{array}$ & \\
\hline 5.Door & Single open door with 0.90 wide, handle with door-knobs & \\
\hline 6.Information & Counter services were for general person, not suitable for the disabled. & \\
\hline 7.Corridor & $\begin{array}{l}\text { The width of walkways in buildings was at } 1.50 \mathrm{~m} \text {. Wide but there were } \\
\text { benches along the way to narrow and no handle rails. }\end{array}$ & \\
\hline 8.Classroom & $\begin{array}{l}\text { Simple classroom, which could rearrange to special case with the } \\
\text { furniture and equipment. }\end{array}$ & \\
\hline
\end{tabular}


From Table 3 found that there were necessary legal requirements for the universal design already the main important elements to access the ramps to enter that really could be used, suitable width, elevator was big sizes, but mostly had no handrails and mirror, indoor pathways were wide, however this was the only one building that had restroom for the disabled persons. In conclusion from case study, the buildings built either before or after the legal requirements still could not be available to support to all people, the importance is only for the way to be reached than other subjects.

4.2 Evaluation of problems and obstacles by wheelchair-bounded student

The results of the survey showed that the physical factors that were affecting to wheelchair-bounded student are ramps, classrooms, restroom and activities area, according to survey results, Tables 2. and Table 3. Access audit by one wheelchair-bounded student. Found that factors affecting are entrance, classroom, restroom and activities area. The results can be described in Table 4 .

Table 4. Shown results of access audit by wheelchair-bounded student

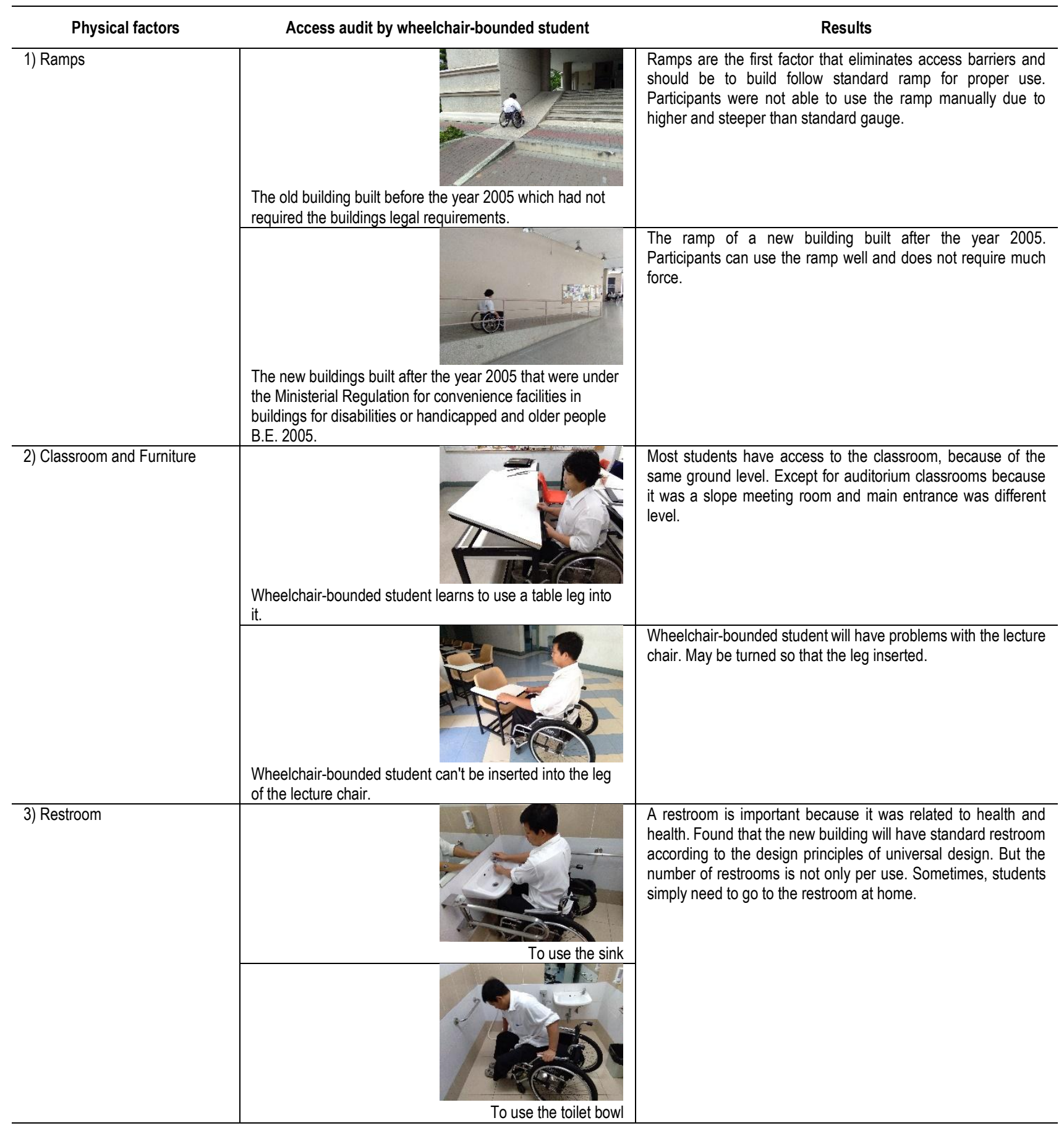


Table 4. Shown results of access audit by wheelchair-bounded student

\begin{tabular}{l|l|l}
\hline \multicolumn{1}{c|}{ Physical factors } & Access audit by wheelchair-bounded student & Results \\
\hline 4) Activities area & campus activity are inaccessible, don't want to be \\
discriminated, because of different levels.
\end{tabular}

\subsection{Attitudes of wheelchair-bounded students about lives in a university}
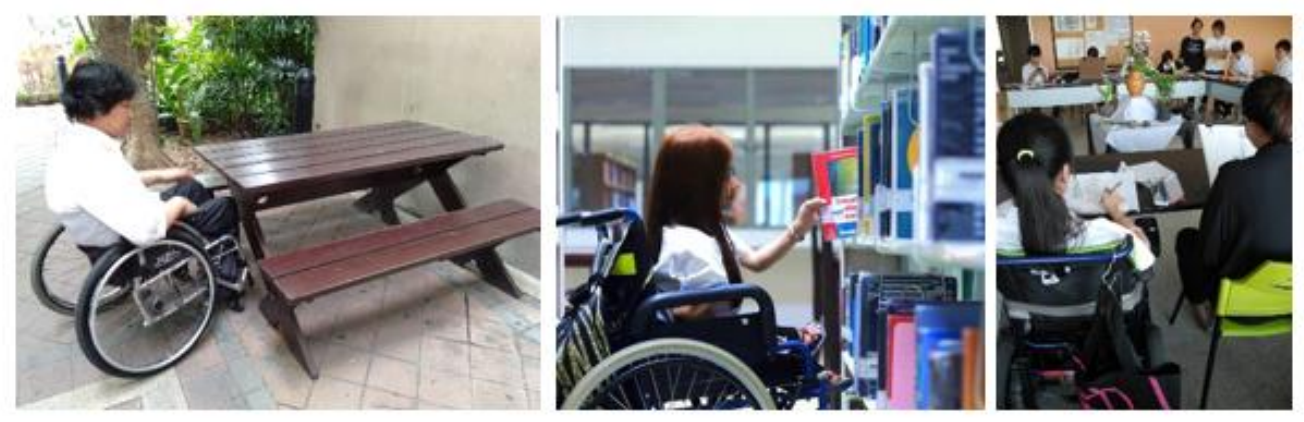

Fig.3 The area of activity of the university students who use wheelchairs, access to the sitting area, access to bookshelves in the library and sharing classes with friends.

The conclusion for second part mostly aimed to the questions from semi-structured interviewing methods will reveal the critical components of the attitude of wheelchair-bounded student's life in a university and lead to other findings by conducting individual interviews.1) Mr.Komsan: 27 years old 2) Ms.Jinjutha: 22 years old 3) Ms.Nattaporn: 24 years old (Fig.3), take in an interview with one person 45-60 Minutes., use a voice recorder, taking note and photography.

Table 5. Shown results of attitudes of wheelchair-bounded students

\begin{tabular}{|c|c|c|c|}
\hline \multirow[t]{2}{*}{ Subject } & \multicolumn{3}{|c|}{ Attitudes of wheelchair-bounded students } \\
\hline & $\begin{array}{c}\text { Interviewee } 1 \\
\text { Male: } 27 \text { years old }\end{array}$ & $\begin{array}{c}\text { Interviewee } 2 \\
\text { Female: } 22 \text { years old }\end{array}$ & $\begin{array}{c}\text { Interviewee } 3 \\
\text { Female: } 24 \text { years old }\end{array}$ \\
\hline $\begin{array}{l}\text { 1. The type of wheelchair } \\
\text { used. }\end{array}$ & Manual wheelchair & Mobility Scooter & Mobility Scooter \\
\hline 2. How to get to university & $\begin{array}{l}\text { Live in the dorm } \\
\text { Come to the university by yourself }\end{array}$ & $\begin{array}{l}\text { Live in the dorm } \\
\text { Come to the university by yourself }\end{array}$ & $\begin{array}{l}\text { Residential home their own } \\
\text { Parents drive transmission. }\end{array}$ \\
\hline $\begin{array}{l}\text { 3. Characteristics of teaching } \\
\text { activities }\end{array}$ & \multicolumn{3}{|c|}{ Class activities can be accessed, outside the classroom, some can be joined. Maybe a friend or instructor should help. } \\
\hline 4. Other activities & $\begin{array}{l}\text { No ramp access to the gym, } \\
\text { Activities for younger children can be } \\
\text { accessed. }\end{array}$ & $\begin{array}{l}\text { Join specific activities that are } \\
\text { accessible. }\end{array}$ & $\begin{array}{c}\text { Attend accessible activities, } \\
\text { Activities organized in the classroom. }\end{array}$ \\
\hline $\begin{array}{l}5 . \text { Access problems and } \\
\text { barriers }\end{array}$ & $\begin{array}{l}\text { The ramp into the new building is } \\
\text { usable, the ramp into the building built } \\
\text { before the year } 2005, \text { will not be } \\
\text { standard. Make it inaccessible to the } \\
\text { building itself. }\end{array}$ & $\begin{array}{l}\text { How to get from dorm to university due } \\
\text { to unfavourable transportation systems, } \\
\text { the ramp enters the building that was } \\
\text { built before the year } 2005 \text {, not standard } \\
\text { or some buildings have no ramp }\end{array}$ & $\begin{array}{l}\text { Ramp into the building With too steep } \\
\text { cause harm. The entrance ramp built } \\
\text { before } 2005 \text { will not be standard or } \\
\text { some buildings have no ramp. }\end{array}$ \\
\hline $\begin{array}{l}\text { 6. Problems and obstacles in } \\
\text { the building }\end{array}$ & $\begin{array}{c}\text { Ground level do not exceed } 10 \mathrm{~cm} \text {. can } \\
\text { be reached. Buildings built before } \\
2005 \text { do not have restroom and in the } \\
\text { new building, there is only one } \\
\text { restroom. }\end{array}$ & $\begin{array}{c}\text { She can't enter a room with raised } \\
\text { floors, auditorium room classrooms are } \\
\text { inaccessible, restroom with a new } \\
\text { building only }\end{array}$ & $\begin{array}{l}\text { She can't enter a room with raised } \\
\text { Push button of elevator, auditorium } \\
\text { room classrooms are inaccessible, } \\
\text { restroom with a new building only }\end{array}$ \\
\hline $\begin{array}{l}\text { 7. Expectations about the } \\
\text { physical aspects of the } \\
\text { university }\end{array}$ & $\begin{array}{l}\text { Students are physically strong. } \\
\text { Did not expect the physical side. } \\
\text { But focus on learning in the curriculum. }\end{array}$ & $\begin{array}{l}\text { Did not expect, because students have } \\
\text { friends before class. }\end{array}$ & $\begin{array}{l}\text { Did not expect, because students have } \\
\text { friends before class. }\end{array}$ \\
\hline $\begin{array}{l}\text { 8. Satisfaction with physical } \\
\text { factors }\end{array}$ & $\begin{array}{l}\text { Because after the students come to } \\
\text { study. The University has improved } \\
\text { physical education to help students and } \\
\text { take care of the staff, but more self-help }\end{array}$ & $\begin{array}{c}\text { University will improve the physical } \\
\text { aspects after the study and a support } \\
\text { staff }\end{array}$ & She can't use in other buildings. \\
\hline
\end{tabular}


The results show that physical factors are essential for the learning of disabled students using wheelchairs. Because they do not have to ask for help from the society. The priority is to built ramp into providing the building, because they can go to other areas. Interviewers 1 and 2 also commented that the institution they studied improved their physical environment after enrollment and that the old building would follow the universal design concept only at the entrance of the building. But not available, because they did not support the proper standard. Interviewees 2 and 3 will have the same opinion. There is a physical aspect to the interviewee. 1 is a ramp because both use Mobility Scooter. But there are similar obstacles. Some buildings have a steep slope or some buildings have no ramp.

\subsection{Conclusion and Recommendations}

From research's results found that wheelchair-bounded students need the first place: a standard ramp in every building, safety, access to all areas of activity. Secondly, restroom for the disabled in every building. Third, classrooms where they can study with friends, and activities areas such as rest areas can be shared with others. The findings of the study found that students who use wheelchairs, but they have good hands and brain, need help because of the unfavourable environment. In fact, they can help themselves. Due to the unfavourable environment, they have to ask for help from their friends. The interview results showed that the proportion of buildings built before B.E. 2005 was higher than that of buildings constructed after B.E.2005. Universal design implementation may be more difficult, due to the cost of renovating older buildings is higher than investing in new buildings. Therefore, the legal requirements might be the first important factor to push to be done in University. It is good, if the law explicitly stipulates for punishment those who do not comply. Since this case study was in private university, which should support and avoid any mistakes to reduce defect, which would cost the damages. The next study to obtain significant information may be conducted with a variety of physical universities. Because, it can see more problems and obstacles.

\section{Acknowledgements}

This research cannot be done without the help and inspiration of Asst. Professor Dr. Antika Sawadsri on issues and research methods. Thank you to Dhurakij Pundit University for data collection and access audit, and all interviewee for their cooperation in this study, 1) Mr.Komsan 2) Ms.Jinjutha and 3) Ms.Nattaporn. Interviews were granted permission to photograph and record the interviews of the three interviewees.

\section{References}

Abdul Kadir Syazwani, M. J. (2012). Building Managers' Perception in Regards to Accessibility and Universal Design Implementation in Public Buildings: Putrajaya case studies. Asia Pacific International Conference on Environment-Behaviour Studies (pp. 129-136). Famagusta, North Cyprus: Elsevier B.V. Selection. https://doi.org/10.1016/j.sbspro.2012.03.072

Abdul Kadir, S., M. J. (2012). Applicability of Malaysian Standards and Universal Design in Public Buildings in Putrajaya. ASEAN Conference on EnvironmentBehaviour Studies (pp. 659-669). Indonesia: Elsevier B.V. Selection. https://doi.org/10.1016/j.sbspro.2012.02.071

Atkinson, Dorris, Miller, Ortiz \& Royal. (2013, April 24). Tarleton State University. Retrieved from Educational Facilities: Universal Design: https://online.tarleton.edu/ACEF/UDIL42413/UDIL42413_print.html

Department of empowerment of persons with disabilities, (2008). Ministerial Regulation: Education for Persons with Disabilities Act 2008, Section 5 [Online]. Available at http://dep.go.th/th/node/432.PDF (Accessed: January 2015).

Department of empowerment of persons with disabilities, (2016). Report on Persons with Disabilities in Thailand, September 2016

[Online]. Available at http://dep.go.th/sites/default/files/files/news/Report_PWDS_SEP2559.pdf (Accessed: December 2016)

Holley Atkinson, D. D. (2013, April 24). http://online.tarleton.edu/. Retrieved from http://online.tarleton.edu/: http://online.tarleton.edu/ACEF/UDIL42413/

Jarutach, T. (2015) Universal design guide book [in Thai: คู่มือการออกแบบเพื่อทุกคน] In Jarutach, T. Operations Unit: Research environment for the elderly and disabled people, the Thailand Research Fund (TRF)

Komolkiti, P. (2008). Life and the restrictions on the path of the disabled in Thailand [in Thai: ชีวิตและข้อจำกัดด้านการเดินทางของผู้พิการไทย]. Journal of Architecture, Chulalongkorn University, 63-77.

Oliver. (1990). The Politics of Disablement. UK, London.

Ostroff, (2001). The Centre for Excellence in Universal Design. Retrieved from http://universaldesign.ie: http://universaldesign.ie/What-is-UniversalDesign/Benefits-and-drivers/.PDF (Accessed: August 2015).

Sawadsri, A. (2012). 'Do I Look Like an Object?' A Quest of Exploring Person -Place Relationship of Disabling. ASEAN Conference on Environment-Behaviour Studies (pp. 418-428). Bangkok, Thailand: Elsevier Ltd. Selection and peer-review under responsibility of the Centre for Environment- Behaviour Studies (cE-Bs),. http://doi: 10.1016/j.sbspro.2012.08.046

Sawangjaroen, C., Sirisali, P., \& Sahavacharin, A. (2012). Assessment of the Physical Environment for Students with Disabilities Thammasat University Rungsit 
Campus. Bangkok: Faculty of Architecture and Urban.

Tieammanee. (2009). Methods of Improving the Providing of Educational Welfare for Disabled Students of Thammasat University at Rangsit Campus' A Thesis for. Thailand: Thammasat University.

Tipian \& Sawadsri. (2017). The Role of Universal Design on Campus and Practical Mobilisation. AMER International Conference on Quality of life (pp. 193-199). Malaysia: E-B Environment-Behavior Proceeding Journal. https://doi.org/10.21834/e-bpj.v2i5.665 